\title{
IMPOSITION/APPROPRIATION OF PATRIARCHY/MASCULINITY IN LAXMI PRASAD DEVKOTA'S EPIC POEM MUNA MADAN
}

\author{
Baburam Khanal, PhD*
}

\begin{abstract}
Muna, the female protagonist of the epic poem "Muna Madan", suffers from prejudices. She becomes the victim of patriarchy. Her effort to resist the imposition of masculinity upon her has been useless ultimately. This paper explores how she appropriates the imposition of masculinity and gives consent to her husband to leave for Tibet. While doing so she remains at home nursing his aged mother, waiting, hoping for his safe return that never materializes until she transforms her from her physical state to the spiritual one.
\end{abstract}

Keywords: Patriarchy, Subaltern, Colonization, Episteme, Domination

... the husband is the master of the household . . . the husband is to be firm, the wife soft, conjugal affections follow from this. Listen carefully to and obey whatever your husband tells you."

(song, c.a. 800 CE, 1995, P. 5 cited in The Good Earth by Pearl S. Buck)

The attitude of patriarchy towards women has been poignantly evoked in these lines. Despite the fact that men and women have equal role and responsibility in all matters today, males are still considered to be firm, bold, and determined, and women weak, subordinate and soft. Such readings/assumptions are common in the characters of Devkota. Prima facie, the characters in this epic poem have similar role and status not only because males are bold and firm, and females are weak and soft but also the patriarchy/masculinity assumes that males are strong by birth and females are shy, weak and soft. And women are passively and passionately appropriating it. Because of this feeling of masculinity, there is still inequality and discrimination on the basis of gender.

There is no doubt that there are gender or biological differences between males and females. But to read female one sidedly along with the line of differences will be a mistake. This research focuses on justifying that the differences are not biological but cultural, that is, the mind set of patriarchy and appropriating attitude females. Madan, the protagonist of Devkota's epic Muna Madan feels that he is physically strong and mentally sound while he is going Tibet and gain financial advantage so that he could improve his status and fulfil the longings of his aged mother. He ignores his wife Muna's voice and determines to go abroad leaving his aged mother and Associate Professor of Saraswati Multiple Campus (Humanities Faculty: English Department), Tribhuvan University,
Nepal. 
beloved wife. His wife's appeal not to leave her alone remains in shadow and unheard though she seems to be ready to struggle and suffer pains while travelling with him. Muna utters:

Nachodi janus he mera prana, akeli malai

Manako banma navivne gari biraha jalai.

Lochanka tara! He mera payra, yo jyoti bilaya,

Ke bhanu ? bhanne ma kehi thiyina, bisa nai pilay.

(Do not go my life, do not leave me alone

Do not light the fire of longing in the forest of my heart

The endless fire of longing in a life apart

... If you poisoned me I would say nothing.

The poem is full of pain, frustration and sadness. Also, it is a longing for prosperity travelling abroad and return to achieve it which every Nepali is prone to expect today. Domination of males, unheard of females' voice, helplessness as well as submission of women and appropriation of masculinity are some of the prominent issues of the epic. On top of that imposition of masculinity remains a major domain in the poem. So, the first and most expected query - what patriarchy is and how it controls the activities of women, - is a pertinent debate today.

The Britanica encyclopedia defines patriarchy as the rules of fathers. It originates from the Greek word patriarches, means father or chief of race which is a compound of patria, lineage, descent from peter, father to rule and govern. Historically, the term patriarchy has been used to refer to autocratic rule by the male head of a family. However, since the late twentieth century, it has also been used to refer to social system in which power is primarily held by adult males. It is a "social and cultural term rather than biological" (928).

In a patriarchal system, the activities of women are determined based on the masculine norms. Male dominated society describes women traditionally as working class who tend to be active and a part of social activities. Land owners and political structures created by power community in the colonial period oppresses them. D. Landry and Maclean Gerald write:

It is well known that the worst victim of the recent exacerbation of the international division of labour are women. They are the true surplus army of labour in the conjecture. In their case, patriarchal social relations contribute to their production as the new focus of super-exploitation (124).

Madan does not wait for the consent of his wife but leaves for Lahsa promising to return as early as possible, probably within seven weeks. He soothes Muna's protest very comfortably exposing his supremacy over her indirectly. He retorts:

Ki mari chhadyo, ki gari chhadyo mardo ko irada

Na hala payri batama mero aansu ko yo badha (1)

(Males are firm and determined. They are committed to do or die.

Do not obstruct my way through your tears). 
In a patriarchal society, it is the law of the male members of the family that controls women's values, dreams and desires, and women have to obey them because as Landry and Maclean assume "they are inescapably patriarchal." (86) Patriarchal system creates situation for the woman as Spivak declares "figure of women"(12) is at issue, one whose minimal prediction as indeterminate is already available to the pholocentric traditoin. She talks about unpleasant situation of the woman in patriarchal societies and under their rules.

Muna's plead to stop her husband from traveling to Tibet could not materialize. She was reminding him about the difficulties he had to undergo through the jungle and mountain, a mid the wild lives. She asked Madan to take her if he really wanted to go because she would protect him in trouble with her affection. She repeats:

bhiraka bhote, banaka jantu gaiko aahara

raeama surje bidama hanso kasari milaun

janenai bhaye nachodi janus sathma suhaun

hajurko gatha hajurko matha pritile samaun (2)

(There are jungles and mountains, Tibetans on the cliffs, wild beasts who eat cows, a smile of farewell is like sunshine at night...

Go if you must, but do not leave me alone

I shall protect my lord's body and face with my love. (2).

Yet, Muna's voice is undermined, ignored. Madan dismisses her advice very easily. He describes the uneven topography of the land- throny bushes, steep hill dales, forest which were difficult to ovecome for female. Further, he asks Muna to look after his aged mother until he returns.

In many colonized societies women like colonial subjects have been relegated to the position of other. They are colonized by various forms of patriarchal domination. They thus share with colonized races and culture and get an intimate experience of the politics of oppression and repression. The notion of double colonization, that is, - women in formerly colonized societies were doubly colonized by both imperial and patriarchal ideologies - became a catch phrase of post colonial and feminist discourses in the 1980s. Ketu Katrak believes that 'feminist politics is inescapably studied within patricular colonized societies' (157-79).

Muna tries to persuade Madan that his mother's weak health and old age could be a problem for her to look after. Most significantly, it was not an ideal time for him to leave for Lahsa. The wealth will not have any meaning in return to mother's health. Further, she urged him to eat neetle and green and be happy rather than expecting to earn gold furn Tibet.

Hathko maila, sunako thaila ke garnu dhanale,

Saga ra sisnu khayeko besa anandi manale (2)

(Begs of gold are like the dirt on your hands what can be done with wealth

Better eat only neetles and greens with happiness in your heart (2). 
Madan ignores her words again. He believes that upon returning from Tibet, he would be able to afford milk for his mother, pay the debt and renovate the house. Also, he will build a rest-house and a water tap in memory of his mother and adorn her with jewelry. He repeats:

Ti aamalai dudhko ghudkole gala rasaun

unako euta pati ra dharako iccha parun.

yo hatalai sunakobala khadilo suhaun

rinale thotro gharako jaga balio banaun (3)

(I will soothe her throat with the sip of milk, settle the debt, renovate the house and construct a rest house and a water tap in memory of his mother, and also he will adorn her with solid gold (3)

Gyatri Chakarborty Spivak believes what is radically piece of writing or politics in one arena can act as a colonizing agent in another. Both women and nature are subordinated by patriarchal capitalist system because economic production is valued higher than non-productive output that women have traditionally been assigned to such things as "strengthening community bonds raising children talking care food and family and mother in-law at home (37).

Muna asks Madan not to forget her and not to fall in love with the Tibetan lass if he wants to go. His departure will ultimately bring darkness at home and city. Madan dismisses her request again, but insists that male can overcome any obstacles as long as they get support from female. He added that he would go to foreign land with love and inspiration from her as Muna has nothing to do but appropriate the imposition of patriarchy.

Women are bound to pass through the phallocentric tradition. They have become subaltern subject in a world of patriarchy where women's position is no longer respected. Frantz Fanon in Black Skin, White Marks, assumes that the track of sexual difference is doubly affected. The ideological construction of gender keeps the male dominant. He agrees with Spivak that if in the context of colonial production, the subaltern has no history and cannot speak, the subaltern as female is even more deeply in shadow (28).

Muna's effort to stop Madan from going abroad continues. She expresses her true love to Madan though she can't disclose it physically. Nonetheless, Madan refuses her words and repeats that since he intended to go, the almighty is sure to fulfill his desire and makes commitment that if he dies while he is accomplishing his best deed, he will live in heaven and have reunion there with Muna.

Subaltern life writing places the individual story in the public domain the distinction between the public and private breaks down. Pain moves outward from the narrator's community and those which cannot be written are narrativised. Pramod Kumar Nayar argues that the subaltern find their identities situated within structure that rejects feminity, race and sexual performance (153).

Sidonie Smith, too, has similar expression. He stresses:

Women are represented as possessing an embodied subjectivity, rooted in their bodies. Women's destiny is determined and limited to her body which she can speak only through selfless service that paradoxically denies her sexuality and body. That is, which 
her social role is determined, by her being biologically female, her biological needs or features are what get marginalized in a society where the man's biology, becomes important. (152)

Spivak agrees that women are doubly colonized in a post colonial society. Their voices are oppressed and ignored and in the hierarchy of structural oppression, there are women who are placed further down the scale.

\section{Muna Madan and Ramayan}

Despite the differences in terms of age, context and content between Ramayan and Muna Madan, some similarities can be observed. According to Ramayan, the central theme of Ramayan is, first, exile, struggle, suffering and eventual return. Secondly, Ramayan persists on the good and evil aspect of the Earth, on has to undergo when s/he faces difficulties. Thirdly, Ramayan emphasizes on the general eastern culture that the eldest son should be dutiful wife should be demure and obedient. Also, as Bikhu Parekh writes "Ramayan stresses on the casteless society though it forced on the virtues of the lower caste", some parallels are to be located if we associate Muna Madan with Ramayan. Madan, the protagonist exiles himself struggling on the mountain through the thorny bushes along the ciffs bearing all the pains and sufferings as Ram Chandra, the protagonist of the Ramayan. Like Ram Chandra, Madan is dutiful and his wife Muna is demure obedient and soft. Also, as in Ramayan, Devkota stresses on the castless society, especially, on humanitarian service. Devkota's character Bhote's service to Madan is an evidence in this regard. Madan touches Bhote's feet without any contempt and disregard for his service to him when he falls ill. Devkota alludes:

Chhetry ko chhoro tyo pau chhuncha, ghinale chhudaina.

Manisha thulo dilale hunchha jatale hudaina

(The son of chhetry touches the feet, but not with hatred.

A man is judged as great by the openness of his heart, not by his caste.).

Women are compelled to stay at home when males went out for business, education, employment and other purposes. Sadly, some of such aspirants like Madan became the victim of some fatal diseases and suffered in disolate places. Women waited at home hoping their early return. Nonetheless their dream did not materialize rather ended in void and chaos. Raghuram Parvati writes.

The imposition of neoliberal agenda has led to the feeling of some forms of trade across the globe while the greater part of the literature on the consequence of this globalization has focused on the role of transnational corporations, more recent work has begun to recognize the significance of emigration from the south in the north who enable linkage between and across the rich and poor nations. (67)

Madan's longing for going abroad for some opportunities could be the part of maintaining the legacy of masculinity. Despite the rejection of Muna, Madan is committed to go abroad and gain advantage. She expresses: 
Manako kura galama adacha, adkancha golame,

Yo mero mutu pachasbaji dhadkincha palama

Yo chhati mero chirera kholi najara garae

Tyo mana kehi pharkhantyo hola, tasbira khulaya

Aansu ma khascha manako tukra yo aanshu boldena

manako kura manamai bascha chatile kholdena.

(words of my heart get stuck in my throat that my breast would brust that you might see your mind might be changed by the picture revealled

A piece of my heart falls in these dumb tears

The heart can not burst, my tears cannot speak).

The urge of his wife did not affect Madan. He still revealed his masculine supremacy over Muna. $\mathrm{He}$ is so determined that he would go to Tibet and gain experience, knowledge and monetary advantage. Rob Nixson assumes:

... in global terms is complicated by its paradoxical position. On the other hand, it stands at the cultural crossroad; nationalism interacts there, mingle and becomes disordered while cultural identities and forms, like wise get dismantled and are recombined ... exorts and international influence in the service of a particular nation (40)

In many cases, woman wanted accompany their spouse but their voices were unheard. They were almost colonized within the domestic environment, controlled and regulated by patriarchy. Hans Bertens writes:

Millions and millions have come and gone under the colonial dispensation without leaving a trace: men but even more so women. Since colonized woman almost by definition went unheard within their own patriarchal culture, they were doubly unheard under a colonial regime. (211)

Patriarchy assumes that women are weak in comparison to men. This notion keeps male at the center and female at the margin which creates an automatic hierarchy. The center bears more importance than the margin. In Muna Madan, Madan, the protagonist, bears similar importance. $\mathrm{He}$ is delineated at the centre and his wife Muna at the margin. Mark Liechty accords that "such hierarchy takes the form of binary opposition" (312). Madan is sketched as young, bold determined- character while Muna as weak, obedient and submissive one.

False claims to knowledge have served as instrument of power of social suppression. The assumed inferiority of women which endless generation of males have accepted as factually true as part of their knowledge of the world. Michael Foucault believes that the power of the males turned into factual knowledge. It does not take much effort to show that "in many cases so called knowledge reflects a relation of power between the subject (the knower) and the object (which the knower knows) rather than what we would call the truth" (155) Madan, too, has similar 
presumption when he leaves for Tibet that as a male he has to get victory and get thrilled. Also, he likes to convey the world that it is the patriarchy that can have a dominant role. Madan recons:

purashko payri ! sangrama sansar bijaya usko sar

purakh bina purusha hunna tarbar binadhar.

(Darling males are born in order to struggle, to fight and thrilled over their victory.

And there cannot be a male without hard work as sword not be without its sharpness (4)

Chandra Talpade Mahanty in Under Western Eyes criticises western views which too easily elides specific cultural difference and naturalize all women's oppression under widely differing manifestations of patriarchal domination to European models. Mahanty views:

... in the form of cross-culturally singular monolithic notion of patriarchy or male dominance leads to the construction of a similarly reductive and homogenous notion what I call the Third World Difference that stable, a historical something that apparently oppresses most if not all the women in these countries And it is the production of this third world difference that western feminisms appropriate and colonize the fundamental complexities and conflicts which characterize the lives of women of different classes, regions, cultures races and castes in these countries. (260)

As Muna's both effort - to stop her husband from going to Tibet or to accompany him-get failure, she passively consents him with total uneasiness of her heart.

Sabari haos adhyaropari ghara ra saharma

rununai bala pugdaina roi aansu le hajurma (3)

(Go on your way if you will bring darkness to this house and this town).

Nepal is an independent country since her formation. The colonial powers were limited only to the southern Ganges basin, across our border. Yet, the sense of colonization was in practice internally in domestic level. Males performed the role of colonizer and rational indirectly and women were given the status of colonized and irrational. Alastair Penny Cook believes that in the colonial period, "colonizers constructed themselves as rational and the colonized as irrational. Also rational men colonized, penetrated, took authority over irrational women" (61). Women's organizations didn't have active role then. The voices of women for freedom, equality and social justice were deliberately weakened. Geetanjali Gangoli rightly points out that social reform that focused on improving women's status was some what weakened in the late nineteenth century ... (16). So, women like Muna had to appropriate masculinity.

\section{Conclusion}

Women in a patriarchal society have become the victim of masculinity. Their role in the foundation of a modern nation has been undermined. The contribution of woman is almost negated. Instead, masculinity is highlighted and widened in the public domain. The universal principle that men and women are equal in all matters including education, economic and legal matters has been rejected outright. Their voices have been unheard, their desires and interests 
have been thrown into shadow. Women have been marginalized and given the uncompromising logo of weak, shy, soft, and irrational by the colonizer rational males.

\section{Works Cited}

Bertens, Hans. "The subaltern". The Basics: Literary Theory, Routledge, 2002, pp. 210-16.

Buck, Perl Sydenstricker. The Good Earth. John Day Company, 1995, p. 5.

Cohen, Robin. Global Diaspora: An Introduction. UCLP, 1999, pp. 62-64.

Devkota, Laxmi Prasad. Muna Madan. Sajha Prakashan, 2059.

Fanon, Frantz. Black Skin White Mask. Grove P, 1967, p. 28.

Foucault, Michael, Power/Knowledge: Selected Interviews and Other Writings. Edited by Colon Gordon, Harvester Wheatsheaf, 1980, p. 155.

Gangoli, Geetanjali, "National and Local Feminism: Different streams within the Women's Movement". Indian Feminisms law, Patriarchies and violence in India. Ashgate, 2007, p. 16.

Hutt, Michael, Devkota's Muna Madan. Translation and Analysis, Sajha Prakashan, 2001.

Katrak, Ketu H. Decolonizing Culture: Toward a theory for Post colonial women's Text: Modern Fiction Studies, Edited by Bill . . 1999, pp. 157-79.

Landry, Donna and Maclean Gerald. The Spivak Reader: Selected Works of Gyatry Chakraborty Spivak. Routledge, 1993.

Liechty, Mark. "Paying for Modernity: Woman and Discourse of Freedom in Kathmandu." Modernity on the Global Periphery. Martin Chautari, P. 2010, p. 314.

Mahanty, Chandra Talpade. "Under western Eyes: Feminist Scholarship and Colonial Discourses". The Post Colonial Studies Reader. edited by Bill Aschroft et al., Routledge, 1999, p.p. 252-53.

Maharshi, Valmaki. The Ramayan, India.

Nayar, Pramod Kumar. Post Colonial Literature: An Introduction, Pearson, 2008, p. 153.

Nixon, Rob. London calling: V.S. Naipaul Post-colonial Mandrain, Oxford UP, 1992, p.40.

Pennycook, Alastair. "Masculine and Feminine: The Construct of Colonialism" English and the Discourse of Colonialism. Routledge, 1998, p. 61.

Raghuram, Parvati, "Fashioning the south Asian Diaspora: Production and consumption Tales" South Asian women in the Diaspora. Berg. Oxford, UP, 1992, p. 40.

Smith, Sidonie. Subjectivity Identity and the body: women's Autobiogrgaphical Practices in the Twentieth century. Oxford University P. 1993.

Spivak, Gayatri Chakrovorty. "Can subalter speak?" The Post Colonial Studies Reader Edited by Bill Aschroft Gareth Griffiths and Welen Tifin, Routledge, 2001, p. 28.

... Can Subaltern Speak? Marxism and the Interpretation of Culture Eds. C. Nelson and L. Grossberg, Routledge, 1998.

The Britannica Ready Reference Encyclopedia, Vol. 81-8131-098-5. Impulse, 2004. 